\title{
Optimizing ICT-based Learning of Social Studies in Primary Schools
}

\author{
Heri Maria Zulfiati ${ }^{1}$, Suyanto $^{2}$, Hadjar Pamadhi ${ }^{3}$ \\ heri.maria@ustjogja.ac.id ${ }^{1}$, suyanto@uny.ac.id ${ }^{2}$,hpamadhi@uny.ac.id ${ }^{3}$ \\ Universitas Negeri Yogyakarta, Yogyakarta, Indonesia ${ }^{1,2,3}$ \\ Universitas Sarjanawiyata Tamansiswa, Yogyakarta, Indonesia ${ }^{1}$
}

\begin{abstract}
In the current era of globalization, Information and Communication Technology (ICT) becomes a fundamental requirement in determining the quality and effectiveness of the learning process. An active, innovative, creative, productive and fun learning process is one of the factors that can support the success of learning because when learning is done in a fun way, then the learning material will be readily accepted and understood by students. To promote the social studies learning, it is necessary to provide a variety learning media. The purpose of using learning media is to clarify the delivery of subject matter and focusing students' attention on the subject matter. Creating a varied and active learning environment is very important, therefore, choosing a strategy using the right learning media is one of the keys. Social studies are one of the sciences related to the development of human life in terms of economy, social relations, culture, history, law and interaction along with the natural environment closely related to the level of human civilization, including today's technology. All aspects of human life are the objects of social sciences study. Therefore, in order to clarify such broad learning materials and experiences, the development of Information and Communication Technology (ICT) for elementary school students is worth considering. In addition, the varied and active learning media is indispensable in learning in today's era. With the principles of effective and efficient use of ICT, the social studies learning will be optimizing, attracting, and stimulating the power of creativity. ICT becomes one of the social learning media which is widely used because it increases the effectiveness and efficiency of learning processes.
\end{abstract}

Keywords: Social Studies, ICT, Primary Schools

\section{Introduction}

Current information and communication technology has an impact on various aspects of life including education. Changes in the learning processes are in line with conventional systems whereas the methods of knowledge transfer uses a blackboard as a principal means of pursuing knowledge from teachers (a teacher-centered approach) by recording and memorizing changes in the learning processes and spaces managed by format statics and teachers become the only source of information developed into in certain places and at particular time spans. Learning usually involves facilities in the form of materials/books such as development and utilization of networking facilities such as computer technology and the Internet. In a current globalized era, ICT (Information and Communication Technology) has become a fundamental requirement in determining the quality and effectiveness of the learning processes. Dryden and Vos [1] conclude from their research that an educational system proves successful if its self-image is more important than the subject matter. Thus, the concept of future education is directed to identify how students learn excitedly. One of the approaches and methods that can be used to improve that aspect is the Information and Communication Technology (ICT) used in the learning processes. [2] who said that Interaction, which can evolve from written correspondence to oral / verbal contacts to video and eventually to face-to-face meetings, has been put forward to build trust between groups through collaboration and cooperation in joint task

Social studies are related to the development of human life both in terms of economy, social relations, culture, history, law and interaction along with the natural environment mainly concerned with the level of human civilization, including today's technology. Students learning in the context of social studies are expected to have the ability to develop the knowledge, values, attitudes and skills of other people, the nation and the state of Indonesia [3]. All aspects of human life are the object of social studies. Therefore, in order to clarify the learning materials, it is necessary to widespread and constantly experience these developments. The growing Information and Communication Technology (ICT) is now very supportive.

ICASI 2018, April 23-24, Medan, Indonesia

Copyright $\odot 2018$ EAI

ISBN: 978-1-63190-162-1 
However, the reality in learning the social studies is extraordinarily problematic and complicated. The complexity evidently shows that the research result [4]shows factual and empirical information at the school level of learning processes and less-optimal efforts of teachers, and empowerment of learning resources because the learning processes of social studies tend to be teacher-centered, textbook-centered, and mono-media. It cannot be blamed unless many students regard the learning processes of social studies as boring, monotonous, less fun, too much rote, less varied, and other relevant complaints. this is reinforced by Syed Noor-Ul-Amin [5]who says that traditional teaching has emphasized the content. Over the years, of course, has been written around textbooks. Teachers have taught through lectures and presentations interspersed tutorial and learning activities designed to consolidate and to train content. Contemporary settings now support curricula that promote competence and performance. Curriculum began to emphasize the ability and more concerned with how the information will be used compared to what the info.

In addition, this situation of social studies learning will make students less focused on learning. When students are bored, they prefer things that they think are more fun, like chatting with friends or conjuring up their own imagination. This condition is beyond the teacher's attention. The processes of learning happen in one way resulting in results, lack of students' attention and mastery of subject matter. Students will not absorb what will be expressed by the teacher if students are not ready to learn. If this condition continues, the teaching objectives cannot be achieved and run unpleasantly. Active, innovative, creative, effective and fun learning processes are determining factors that can support the successes of learning. If learning is done in a fun way, the learning materials will easily be accepted and understood by students. To overcome a dull way of learning social studies, it is important to use learning media. The purpose of using learning media is to clarify the delivery of subject matter and focus students' attention on the subject matter. Creating a varied and active learning environment is very important, therefore, choosing a strategy using the right learning media is one of the keys to success.

Information and Communication Technologies (ICT) is one of the varied and active learning media for activities such as processing, manipulation, management, and transfer of information. ICT covers two aspects, namely information technology and communication technology. ICT is indispensable to support the learning processes in today's era. The principle is that the effective and efficient use of ICT can optimize, attract, and stimulate creativity. ICT becomes one of the learning media which is widely used in various fields of education because it increases the effectiveness and efficiency of learning processes. This is in line with Ismail Darimi's [6]opinion that ICT functions and roles are very important so that the learning process in schools can be more straightforward in finding information, manipulating, managing and transferring knowledge or transferring information, and integrating. students' thinking skills, developing skills, and students to learn.

According to Munir [7], the ICT implementation not only requires support from the resources factor (human resources) but also the facilities. The resources factor and infrastructure facilities are closely interrelated, for example, the school provides infrastructure or facilities but it is not a guarantee that the application of ICT can run properly. This likely happens in some schools in the Special Region of Yogyakarta where the facilities and infrastructure of ICT are strongly adequate, they are not optimally used as media of learning. The Special Region of Yogyakarta was appointed as the pilot project of ICT Eqep Program from 2009 to 2011. This province provides assistance from Kyoto Province of Japan through the Ministry of Communication and Information. The assistance was realized in 2010 that involved 500 schools consisting of 200 schools for junior high schools and 300 schools for Primary Schools eligible for such assistance. In addition to 21 units of computers, the assistance also provides the LCD Projector, Projector screen, and CD learning media. Being assisted by computer facilities, teachers in these schools have been trained to utilize existing facilities in terms of content, and hardware. To accompany the utilization of ICT in learning through ICT EQEP program, the Hall of Shipping Safety Technology (BTKP) of Yogyakarta has also formed an ICT Developer Team consisting of 40 people spreading throughout the Regency or City. If the school encounters technical and non-technical problems, the Hall of Shipping Safety Technology (BTKP) of Yogyakarta has formed a Helpdesk Team of EQEP ICT Program consisting of 5 people, each of which handles one Regency or City. Thus, there is no absolute reason for schools not to take advantage of the EQEP ICT assistance program. However, despite the complete facilities and infrastructure related to the ICT equipment, in fact, the observation in the field at that time indicates that some schools have not utilized the ICT as one of alternative media of learning. This can be seen from the limited use of computer for the ICT-based learning of social studies. Busyness and time constraints become obstacles for teachers to design materials to facilitate ICT as a medium of learning. 


\section{Method}

The method in writing this article is to examine the sources relevant to the problem, both in line and contradictory. The referenced sources are relevant articles of thought, previous research results and also theories extracted from textbooks. Social studies in primary schools are a field that studies human beings in all aspects of life and interaction with the community to develop children so that they become active in the field of knowledge (cognitive), attitude (affective), and skills in the school environment. Social studies are also used to develop the children's morality to form habits in everyday life. Savage [8] in a book entitled Effective Teaching in Elementary Social Studies points out that until now there has been no consensus on the subject matter of social studies. The goal of social studies is declared by the National Council for Social Studies (NCSS), a professional association of educators in the social field often used as a Social Studies are integrated with social sciences and humanities to promote the civic competence. Within the school program, social studies, coordination, archaeology, economics, geography, history, law, and philosophy contain appropriate values of humanities, mathematics and the natural sciences.

\section{Discussion}

Social studies are an integral part of social sciences and humanities in developing citizenship competence. In the school program, social studies are a coordinated and systematic study of a subject developed from various disciplines such as anthropology, archeology, economics, geography, history, law, philosophy, political science, psychology, religion, sociology, humanities, mathematics, and the natural sciences. Martorella [9]identifies that social studies are an integration of experience and knowledge concerning human relations for the purpose of citizenship education. It means the social studies is a combination of experiences and sciences that pay attention to human relationships for the purpose of civic education. Muhammad Numan Sumantri in Tasrif [10] emphasizes that social studies education is a simplification of the disciplines of social sciences, state ideology and other disciplines as well as related social issues organized and presented scientifically and psychologically for the purpose of education at the basic and medium levels.

Events, facts, concepts and generalizations related to social issues are some of the things that social studies identify. The sequence of events shows the order of form from the most concrete, i.e., from the event to the abstract level that articulates concepts. In Jarolimek's term [8], the role of events and facts in constructing concepts and generalizations deals with factual information to support details and elaborate meanings. This means that information about facts has a significant contribution to the understanding of concepts and generalizations because they provide detailed support and extensions that make concepts and generalizations meaningful. Therefore, social studies are a fusion of various branches of the social sciences, such as anthropology, language, economics, philosophy, geography, law, history, sociology, politics, and social psychology. Social studies are formulated a basic reality of and social phenomena for embodying an integrated approach of social sciences. Social studies are a part of the school curriculum derived from the content of social sciences. Social studies are one of the sciences that pertains to the development of human life both in terms of economic and social relations, culture, history, law and interaction. This natural environment is closely related to the level of human civilization including today's technology. All aspects of human life are the objects social studies. Therefore, in order to clarify the learning materials in relation to the widespread and constant experiences, the growing information and communication technology (ICT) is now very supportive.

Information and Communication Technology (ICT) is a large umbrella terminology that includes all technical equipments for processing and conveying information. ICT covers two aspects, namely information technology and communication technology. Information technology encompasses processes, tools, manipulations, and information managements. Communication technology is something related to the use of tools to process and transfer data from one device to another. According to Evans Wema [11] in International Journal of Education and Development (2010, Vol. 6, Issue 1, pp. x-x), Information and Communication Technologies (ICTs) can be defined as the techniques and tools used to access information and communicate with others. The term refers to electronic and computer based technologies. Information and Communication Technology (ICT) can be defined as the techniques, methods and tools used to access information and communicate with others. This term refers to electronics and computer-based technologies. Tinio defines ICT as a set of tools used to communicate and create, disseminate, store, and manage information [12]. The technologies in question include computers, the Internet, broadcasting technology (radio and television), and telephones. Information technology and communication technology are two inseparable concepts. Information and Communication Technology contains a broad understanding that all activities are related to processing, manipulation, management, transfer of information between media. 
The rapid development of information and communication technology demands a change of learning which originally centers on the teacher and a learning center for learners. The change of learning coincides with an among system, a terms coined by the father of education of Indonesia, Ki Hadjar Dewantara. The among system is an authentic idea of Indonesian son taken directly from local wisdom, and educational system implemented by giving freedom to learners to act freely as long as the rules concern, so that this system can foster self-confidence, aspirations and activities of learners. Even this system can become the pre-eminence in Indonesian education in facing inter-state educational competition and a niche (a distinctive, superior system) in facing global educational competition. Among system is a manifestation of Ki Hadjar Dewantara's conception in placing students as the central process of education.

The principle of among system is to give the learners the flexibility to understand the teacher's information and problems based on their age. Furthermore, this system, Teachers must create (1) teaching materials that do not burden learners, (2) methods that provide or are adapted to the conditions of learners' more wisely used of flexible education toward the lesson materials, (3) learning motivation is perceived, if necessary, by looking at the situation of ing ngarso sung tulodha, ing madya mangun karso, tut wuri handayani, interpreted as not necessarily in sequence with dogmatism, meaning that teachers must be adequate from ing madya or tut wuri first. The teachers' position is mainly concerned with the situation or condition of learners, (4) education that should be able to please the learners by giving freedom of expressions [13]

In such a system learners are placed as central figures both as objects and subjects in the educational process, whereas the implementation of education is based on the spirit of kinship, nature and independence that allows the dialogical interaction between teachers and learners. This paradigm change of learning will encourage learners to keep proactive in searching, exploring, and constructing knowledge without depending on the sciences transferred by the teacher. This learning change will result in independent learners so as to construct knowledge either independently or in groups so as to support the success of learning. Munir [12] explains that the use of ICT-based learning media will support the success of learning, because it has the following advantages:

1. Provide a deeper understanding of the learning materials under discussion because it can explain difficult or complicated concepts in an easy but simple way.

2. Explain the abstract learning material or object (unreal, invisible directly) to be concrete (real, visible, felt, or touched) such as explaining blood circulation and human organs.

3. Help teachers to present learning materials in an easy way, so that learners can understand such materials easily and remember them for a long period of time.

4. Attract and arouse students' attention, interest, motivation, activity, and creativity to learn and entertain them.

5. Encourage students' participation in the learning processes and give a deep impression to the students' mindsets.

6. Learning materials that have been studied can be repeated again (playback), for example, by using a recording.

7. Create a conducive learning environment, so that students can communicate and interact with the learning environment and group members' real and direct experiences.

8. Shape students' attitude (affective aspects) and improve skills (psychomotor).

9. Students learn according to their characteristics, interests, needs and talents, whether individual, group or classical learning types.

The following table shows some of the differences between an active learning style and a traditional learning style in which students are lees active in the teaching processes. 
Table 1: Differences between an active learning style and a conventional learning style

\begin{tabular}{|c|c|c|}
\hline FACTORS & $\begin{array}{l}\text { TRADITIONAL LEARNING } \\
\text { STYLE }\end{array}$ & ACTIVE LEARNING STYLE \\
\hline Teacher & $\begin{array}{l}\text { Delivering knowledge or } \\
\text { information to passive students }\end{array}$ & $\begin{array}{l}\text { Provide convenience to create conditions so that } \\
\text { students can learn independently }\end{array}$ \\
\hline Students & $\begin{array}{l}\text { who receive only knowledge from } \\
\text { the teacher by recording or } \\
\text { memorizing. Students only interact } \\
\text { with the teacher }\end{array}$ & $\begin{array}{l}\text { Learning by doing, learning by processes. } \\
\text { Students interact with teachers, with other } \\
\text { students, resources or instructional media } \\
\text { including computers (Internet) }\end{array}$ \\
\hline $\begin{array}{l}\text { Students' } \\
\text { strategies }\end{array}$ & Formal, rigid, no variations & $\begin{array}{l}\text { More emphasis on individual activities to } \\
\text { interact with teachers, with fellow students, or } \\
\text { with the environment. }\end{array}$ \\
\hline $\begin{array}{l}\text { Students' } \\
\text { teaching } \\
\text { materials }\end{array}$ & Course books & $\begin{array}{l}\text { All materials, tools or the environments can be } \\
\text { learning materials. }\end{array}$ \\
\hline Media & Whiteboards and printed books & Media by design and media by utilization \\
\hline $\begin{array}{l}\text { Classroom } \\
\text { management }\end{array}$ & $\begin{array}{l}\text { Conducted in the permanent } \\
\text { classroom where students always } \\
\text { face the whiteboard. }\end{array}$ & $\begin{array}{l}\text { Students sit in rolling, i.e., they can move } \\
\text { according to the needs of learning materials good } \\
\text { for individual learning, in pairs or in groups. It } \\
\text { can also be done elsewhere with e-learning } \\
\text { system or distance learning }\end{array}$ \\
\hline
\end{tabular}

Source: Munir (2010:90)

Information and communication technology is basically a medium that can be used in the learning processes. Using ICT is very helpful for students to obtain and process information as a source of material.

The information system is a set of components to collect, distribute, store, and process data to present information. In various forms of organizations, this information is necessary for both operations and managements. Amajor information system currently builds in information technology supported by telecommunications and computers or other computer-based information systems known as Information and Communication Technology in Indonesia.

In practice, ICT is a medium and a source of learning. Learning requires interaction. A student will gain positive knowledge, skills, and attitudes with the help of a teacher, coach, or instructor. Here is a two-way communication process between students and teachers. In essence, this shows that the learning process is a communication process. This means that a learning process occurs when delivering a message from someone (a message source) to a person or a group of people (the recipient of the message). One of the most widely used models in the communication process is the circular model created by Osgood and Schramm in Canggara, $\mathrm{H}$ [14], as shown in the following figure:

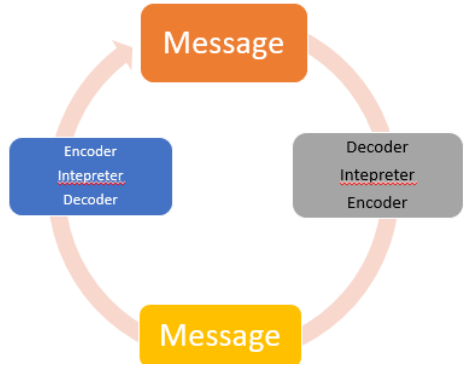

Fig. 1. A process of communication 
The message in question is sent by the communicator in the form of information from the sender (a source) message. The messages are transmitted in the form of codes or symbols such as words, sounds, pictures, and so on, through channels such as the telephone and radio, television, movies and messages received by the recipient through the sight and hearing senses) to be processed, so that the messages conveyed by messengers can be accepted and understood by the communicant.

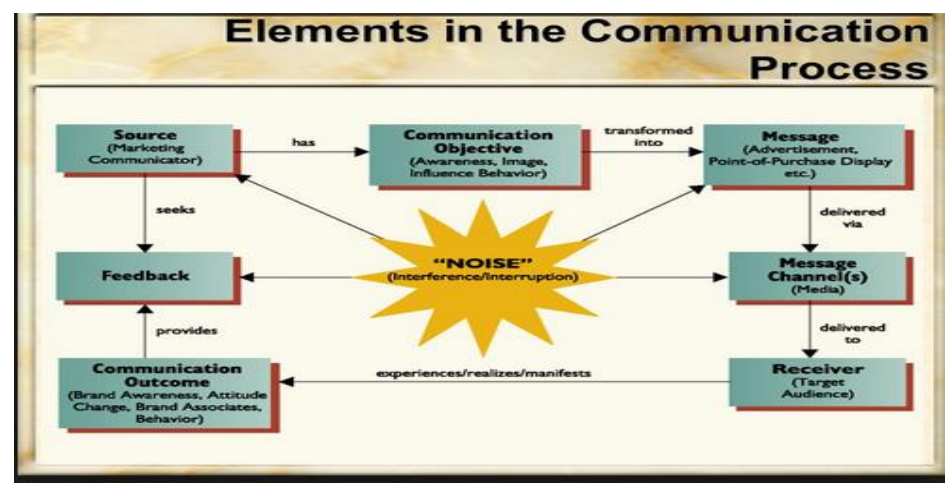

Fig. 2. Elements of communication

Source: http://slideplayer.com/slide/6028646/

Figure 2 shows that the interactive communication between people can only happen if there are communicators, communicants, messages, channels, feedback, disturbances and obstacles. Messages delivered by communicators are forwarded by the channel to the communicant as the recipient of the message. Feedback provided by the communicant will show whether ot not the message is understood by the communicant. Positive feedbacks indicate that messages are well understood, whereas negative feedback suggests that messages may not be properly understood.

Interactive communication can succeed if students in the learning processes not only act as the recipient of the message, but also as a messenger. In that condition, interactive communication will occur between teachers and students, so that learning is more fun and will facilitate the delivery of messages, the communication in Figure 2 evidences a learning process that creates a dialogical interaction between the teacher and students. This is because the teacher not only provides teaching materials as a good and necessary educator, but also facilitates students to construct knowledge. Thus, the use of ICT-based learning media is an alternative that can help students enrich experiences in using the ICT-based learning model. The strength of this mode is that it can provide an active learning alternative for students and it helps students understand abstract things more easily. Students are ultimately motivated to pursue social sciences to the best of their abilities.

\section{Conclusion}

Using the ICT-based learning model in learning social studies absolutely necessary for primary school-aged children. This is because the theory of cognitive development proposed by Piaget highlights that the ICT-based learning using computers describe some abstract processes used for primary school-aged children. At the age of 7 years old and above, children are in the formal operational period so they have been ready to think about abstract things. Therefore, primary school children are able to use abstractions and distinguish between real and concrete things. Primary or juvenile age children are also able to test a hypothesis and be able to generate a scientific reasoning ability. Primary school-aged children have characteristics that experts often classify as creative individual traits, have great curiosity, love to ask, high imagination, broad interests, and excitement about new things. The characteristics of learning objects in social sciences are related to the development of human life both in terms of economy, social relations, culture, history, law and interaction. The natural environment also plays an important role in reaching the level of human civilization including today's technology. The social sciences study the abstract objects for primary school-aged students who are impressed with tedious and rote subjects. Thus, information and communication technology is developed more rapidly as a medium to grasp abstract things and clarify the materials so that learning activities are more fun, interactive, motivated and full of interests. Students will have high learning motivation to achieve high passing grades. In 
addition, ICT-based teaching media enables optimal involvement of students' senses to present a textual and multidimensional display along with interactive conclusions. The view can make users choose things more freely, and elaborate the knowledge they want to understand.

\section{ACKNOWLEDGEMENTS}

This research is fully supported by Affiliation Research Grant from Ministry of Research Technology and Higher Education of Republic of Indonesia with a contract number: PDD.DIKTI.02/UST/LP3M/K/III/2018.

\section{References}

[1] J. Dryden, G \& Vos, Revolusi Cara Belajar. Bandung: Kaifa, 2003.

[2] A. G. Elaine Hoter, Miri Shonfeld, "Information and Communication Technology (ICT) in the Service of Multiculturalism," in Regional Focus Issue: Bridge over Troubled Waters $\sim$ Cengiz Hakan Aydin and Yoram Eshet-Alkalai, IRRODL Regional Editors for the Middle 2 East, 2009.

[3] Depdiknas, Peraturan Pemerintah Pendidikan Nasional No 22, Tahun 2006, tentang Standar Isi Pendidikan. 2006.

[4] H. M. Zulfiati, "Pengaruh PembelajaranIPS Berbasis ICT (Information And Communications Technology) Dengan Aplikasi Lectora Inspire Dalam Meningkatkan Hasil Belajar Siswa,” Jipsindo, vol. 2, no. 1, pp. 66$82,2015$.

[5] S.-U.- Noor, "An Effective use of ICT for Education and Learning by Drawing on Worldwide Knowledge, Research, and Experience: ICT as a Change Agent for Education," 2013.

[6] I. Darimi, “Teknologi Informasi dan Komunikasi sebagai Media,” vol. 1, pp. 111-121, 2017.

[7] Munir, "Kontribusi Teknologi Informasi dan Komunikasi (TIK) dalam Pendidikan di Era Globalisasi Pendidikan Indonesia,” J. Pendidik. Teknol. Inf. DAN Komun., no. 2, pp. 1-4, 2009.

[8] D. G. Savage, T. V, \& Amstrong, Effective teaching in elementary social studies (third edition). New Jersey: Prentice Hall, 1996.

[9] P. . Mortorela, Social studies for elementary school children. New York: Macmillan College Publishing Company, 1994.

[10] Tasrif, Pengantar Pendidikan Ilmu Pengetahuan Sosial. Yogyakarta: Genta Press, 2008.

[11] A. Consolata and W. Evans, "Availability and usage of ICTs and e-resources by livestock researchers in Tanzania: Challenges and ways," Int. J. Educ. Dev. using Inf. Commun. Technol., vol. 6, no. 1, pp. 53-65, 2010.

[12] Munir, Kurikulum Berbasis Teknologi Informasi dan Komunikasi. Bandung: Alfabeta, 2010.

[13] H. Pamadhi, Pendidikan Seni (Hakikat, Kurikulum, Pendidikan Seni, Habitus Seni dan Pengajaran Seni untuk Anak). Yogyakarta: UNY Press, 2010.

[14] C. Hafied, Pengantar Ilmu Komunikasi., 4th ed. Jakarta: PT. Raja Grafindo Persada, 2004. 